\title{
Assessment of heavy metal pollution resulting from informal E-wastes recycling in the Greater Accra Region of Ghana
}

\section{Albert Kwame Teye}

Kwame Nkrumah University of Science and Technology

Isaac Kow Tetteh ( $\square$ iktetteh.cos@knust.edu.gh )

Kwame Nkrumah University of Science and Technology https://orcid.org/0000-0002-0093-0094

\section{Research}

Keywords: E-waste recycling, heavy metals, Igeo, PLI, CF, Spatial distribution, Ashaiman scrapyard

Posted Date: May 3rd, 2021

DOl: https://doi.org/10.21203/rs.3.rs-390412/v1

License: (c) (1) This work is licensed under a Creative Commons Attribution 4.0 International License.

Read Full License 


\section{Abstract}

This study investigated the levels and spatial distributions of four selected heavy metals in the soil and drainage components emanating from informal E-waste recycling activities at Ashaiman scrapyard, in the Greater Accra Region, Ghana. The metals are Cadmium (Cd), Chromium (Cr), Copper (Cu) and Lead $(\mathrm{Pb})$. Five sampling sites were randomly selected, with top and sub-soil sampled from the two open burning areas (hereafter $\mathrm{H}$ and $\mathrm{F}$ ). Three sites in the drainage that runs through the scrapyard were similarly selected for sample collection; a control upstream (soil-sediment-water; WSC) and two experimental units downstream (soil-sediment-water; WS1 and surface water only; WS2). Four control topsoil samples were taken at distances of 25, 50, 75 and $100 \mathrm{~m}$ away from the scrapyard. Composite sample of three sampling units per site, including $\mathrm{pH}$ analysis, with two replications per treatment, were investigated using standards methods. Spatial distribution of the metals in the scrapyard were analyzed using Inverse Distance Weighted (IDW) interpolation method. Coefficient of variation (CV) was used to investigate the source of pollution. The pollution levels were investigated using three criteria, namely Geoaccumulation Index (Igeo), Contamination Factor (CF) and Pollution Load Index (PLI). Correlation analysis was used evaluate the relationships between the metals. Mean CV of $88.5 \%$ suggests that the scrapyard pollution is anthropogenically-driven. Igeo of soil samples from the scrapyard revealed the following: (i) $\mathrm{Cd}$ and $\mathrm{Pb}$ (unpolluted to strongly polluted), (ii) $\mathrm{Cu}$ (unpolluted to moderately polluted), and (iii) $\mathrm{Cr}$ (unpolluted). CF revealed the following: (i) $\mathrm{Cd}$ (moderate to strong pollution), (ii) $\mathrm{Cu}$ (moderate pollution), (iii) $\mathrm{Cr}$ (low pollution), and (iv) $\mathrm{Pb}$ (high pollution), but the metals exhibited moderate PLIs. Spatial distribution maps revealed heavy metal pollution decline with distance away from the scrapyard, which was inversely related to $\mathrm{pH}$ levels. WSC showed lower heavy metal concentrations than WS 1 , while the lowest levels were detected in WS 2. Generally, moderate to very strong correlations existed among the metals in the scrapyard. In conclusion, the scrapyard was the epicenter of E-waste pollution primarily driven by human activities.

\section{Introduction}

E-wastes cover Electrical and Electronic Equipment (EEE) and their parts that have been discarded by their owners as wastes without the intent of re-use or recycling. Due to their different lifespan profiles, different E-wastes have different environmental and health impacts as well as different economic value [1]. Owing to rapid changes in technological updates and upgrades of EEE, industrialization and modernization, increase in disposal income and the popularized increase in the use of EEE, there is an upsurge in the acquisition and utilization of electrical and electronic products. Consequently, the generation of E-wastes is one with the largest and fastest growth rates among wastes in the world. Asia contributed most to the generation of E-waste in 2019, generating close to 24.9 million metric tons (Mt), followed by Europe (12.0 $\mathrm{Mt})$, Americas (13.1 Mt), Africa (2.9 Mt) and Oceania (0.7 Mt) [1, 2].

As a result of free and illegal trading activities and the lack of implementation of environmental policies, African countries receive high quantities of potential E-waste materials from developed countries. Nigeria and Ghana are notably mentioned [3]. Around 600,000 of used EEE were imported into Nigeria in 2010. 
Also, close to $30 \%$ of second-hand imports into the country were considered non-functioning and thus regarded as E-waste. Ghana's E-waste quantities rose from 63,000 tons per year in 2003 to 169,000 tons per year in 2008 with a further increment to 215,000 tons in 2009 . Only $30 \%$ of the total electrical appliances that arrived in Ghana in 2009 were determined to be new, with the rest regarded as used products, $15 \%$ of which were either faulty or outmoded and thus could not be sold, eventually ending up in the informal recycling sector [4].

However, E-waste materials in Africa are poorly managed, due to unawareness of the public on the dangers of poor disposal systems, lack of safe systems of disposal, absence of government policy and legislation or the enforcement of same and the domination of E-waste management by the unhindered and badly equipped informal sector [1]. Manual dismantling, open burning and land filling, of E-wastes result in the release of toxic substances, including polycyclic aromatic hydrocarbons (PAHs), organochlorine compounds, phthalates and heavy metals $[2,5]$. The release of these compounds results in atmospheric pollution, soil acidification and leaching, polluting both ground and surface waters. Soil composition and viability to support plant life is compromised severely following E-waste contamination while deteriorating the quality of water resources causing a reduction in their physicochemical characteristics including $\mathrm{pH}$, phosphate, oxygen and chloride levels [6, 7]. Essentially, poor E-waste management has a negative outlook on the realization of the Sustainable Development Goals (SDGs), particularly Goals 3 (Good Health and Well-being), 6 (Clean Water and Sanitation), 8 (Decent Work and Economic Growth), 11 (Sustainable Cities and Communities), 12 (Responsible Consumption and Production) and 14 (Life Below Water) [1].

Heavy metals are significant components of E-wastes. The application of these metals in electrical gadgets is influenced by factors such as good electrical conductivity to minimize power losses, providing an inert environment in operations to ensure reliability of functioning as well the use of metals compatible with manufacturing processes [8]. Approximately $60 \%$ of E-wastes constitute metal such as gold $(\mathrm{Au})$, copper $(\mathrm{Cu})$, iron (Fe) and tin ( $\mathrm{Sn})[2,6]$. The parent circuit board of many electrical gadgets houses many heavy metals, including arsenic (As), cadmium ( $\mathrm{Cd}$ ), lead $(\mathrm{Pb})$ and mercury $(\mathrm{Hg})$ [2]. Also, $\mathrm{Pb}$ constitutes close to $0.4-1.0 \mathrm{~kg}$ of the total mass of cathode ray tube found in computer monitors and television sets respectively.

Heavy metals released during informal E-wastes recycling are absorbed into living tissues usually through the inhalation of toxic fumes and particulate matter, and ingestion of contaminated food and water [5]. Cd is a known carcinogen of the lungs, kidney and prostate, and also induces abdominal pains and infertility. Exposure to chromium ( $\mathrm{Cr}$ ) causes cardiovascular diseases, haematological and neurological effect and sometimes even death. Pollution resulting from $\mathrm{Pb}$ induces memory loss, dullness, sperm damage and miscarriages, while gastrointestinal effect including nausea and diarrhea, as well as neurological effect and male infertility stemming from sperm damage, result from exposure to $\mathrm{Cu}[9,10]$. 
E-waste recycling activities in Ghana is dominated by the informal sector, largely due to poor implementation of environmental related laws, and also for socio-economic reasons. It is estimated that between 121,800 to 201,600 individuals are involved in the informal E-waste sector in Ghana. The formal recycling sector in Ghana receives only about $0.2 \%$ of E-waste for treatment [11]. Unsurprisingly, Ghana is noted for having one of the biggest informal E-waste recycling in Africa, at the Agbogbloshie scrapyard.

This research was to assess the levels and spatial distributions of selected four heavy metals $(\mathrm{Cd}, \mathrm{Cr}, \mathrm{Pb}$, $\mathrm{Cu}$ ) at an informal E-waste recycling site and evaluate their levels based on permissible ranges specified by the World Health Organization (WHO), Food and Agricultural Organization (FAO) of the United States and the Environmental Protection Agency (EPA) of Ghana. The second objective was to investigate the degree of pollution using geoaccumulation index (Igeo), contamination factor (CF) and pollution load index (PLI). The rest of the paper are organized into the following sections: (i) Sect. 2 describes data and methods, (ii) Sect. 3 is devoted to results and discussion, and (iii) Sect. 3 describes the conclusion, recommendation and future work.

\section{Materials And Methods}

\subsection{Study area}

The Ashaiman scrapyard is located at the entry into the township from the Tema

metropolis, about $0.12 \mathrm{~km}$ from the Accra-Tema Motorway. Covering a land size of about $0.07 \mathrm{~km}^{2}$, it is located on latitude $05^{\circ} 41^{\prime} 4.99^{\prime \prime} \mathrm{N}$ and longitude $00^{\circ} 01^{\prime} 37.28^{\prime \prime} \mathrm{W}$. The region is generally flat with savannah grasses and shrubs being the dominant vegetation. The topsoil is mostly sandy-clay, with the subsoil being predominantly clay [12].

The scrapyard (Fig. 1), adapted from Okine [13], houses large metal containers which store E-waste materials until they are ready to be worked on. Dismantling and sorting activities are performed in sheds and wooden structures at sections of the scrapyard while majority of the burning is done on the open field, though few burning activities are done at the dismantling and sorting areas. At the time of research, two main sites were identified where open burning was taking place. E-waste materials found in the scrap yard included refrigerators, television sets, computers, cables, radios and incandescent light bulbs.

Located very close and separating the scrapyard from a dumpsite is a drain that flows from the northern end of the scrapyard and serves as irrigation for farm crops and drinking water for herds of cattle. The aerial view of the sampling points for the study is displayed in Plate 1.

\subsection{Sample collection}

\subsubsection{Soil samples}

Two burning sites (hereafter Site F and Site $\mathrm{H}$ ) were chosen for soil sampling. Site $\mathrm{F}$ is located at the central portion of the scrapyard. Major parts of this site were used for open burning of E-wastes, though 
few sections served as dumping grounds material after dismantling, sorting and burning. Site $\mathrm{H}$ lies closer to the drain running through the scrapyard. This site is used both for open burning and dumping of E-waste materials.

Samples were taken in the early morning of $16^{\text {th }}$ July 2019 . At each burning site, five top soil samples were randomly taken at five different sites (marked as $1 \mathrm{~A}, 2 \mathrm{~A}, 3 \mathrm{~A}, 4 \mathrm{~A}$ and $5 \mathrm{~A}$ ) within a soil depth of 0-10 $\mathrm{cm}$ and five subsoil samples from the sites but different level (marked as 1B, 2B, 3B, 4B, and 5B) within a depth profile of $10-20 \mathrm{~cm}$. Thus, from each burning site 10 soil samples were taken, and a total of 20 samples were obtained from the two burning areas. Four other top soil samples were randomly taken at distances of 25, 50, 75 and 100 m from the scrapyard (marked as HV 20, HV 50, HV 75 and HV 100, respectively) to determine the horizontal distance from the scrapyard at which levels of heavy metals will be detected and also serve as control as well as background conditions for assessing the pollution levels. At all the sampling sites, a composite sample made up of three sampling units was collected. Soil samples were collected using newly purchased stainless-steel garden shovel and a standard measuring rule to determine the vertical depth of the soil profile. Samples were collected into plastic bowls with tightly fitting lids pre-cleaned with nitric acid. They were then sent to the Ghana Standards Authority for further treatment and analysis.

The coordinates at sampling points were recorded using GPS software.

\subsubsection{Water samples}

A composite of three sampling units of soil-sediment-water was collected upstream about $140 \mathrm{~m}$ from the scrapyard and as control (WS C). A similar procedure was replicated for two experimental units, namely soil-sediment-water samples (WS 1) at $50 \mathrm{~m}$ and purely surface wastewater (WS 2) at about $70 \mathrm{~m}$ both downstream of the scrapyard. These sampling stations were randomly selected from a range of stations that were accessible. Samples from WSC, WS 1 and WS 2 were used to test the hypothesis that high levels of heavy metals are expected to be sediment than the surface wastewater. Coordinates were measured using GPS software. $\mathrm{pH}$ of these samples was measured on site using a handheld HANNA pH meter calibrated with buffer solutions of $\mathrm{pH} 4,7$ and 10 . The samples were collected and sent to the same place just as the soil samples.

\subsection{Sample preparation and $\mathrm{pH}$ determination}

\subsubsection{Soil sample preparation and $\mathrm{pH}$ determination}

Soil samples were air dried at around $105^{\circ} \mathrm{C}$ to eliminate wetness and obtain constant weights representative of the soil only. They were then passed through a $2 \mathrm{~mm}$ non-metallic mesh to separate and remove rocks exceeding $6.35 \mathrm{~mm}$. The soil particles passing the mesh were thoroughly homogenized by manual milling with a mortar and pestle. These preparations were necessary for good dissolution during chemical treatments and increasing the accuracy of the sample analysis [14]. To three grams of each of the dried and sieved soil samples in a $25 \mathrm{~mL}$ beaker (which had been pre-cleaned and thoroughly washed 
with distilled water), $15 \mathrm{~mL}$ of aqua regia were added and the resulting sample solution digested in a fume chamber for about 30 minutes to remove any foreign material that might interfere with the analytical results. Following cooling, there was addition of distilled water to the digested soil sample. This was then filtered into a $100 \mathrm{~mL}$ volumetric flask using the Johnson test paper filter paper with a diameter of $125 \mathrm{~mm}$. Distilled water was then added to the solution to the $100 \mathrm{~mL}$ mark. Spatial distributions of topsoil and subsoils were determined using Inverse Distance Weighted (IDW) interpolation method [15].

The soil pH analysis was conducted following the procedure described by Al-Busaidi et al. [16] by dissolving two grams of each sample in distilled water in a 1:1 ratio and stirred to a uniform suspended mixture using a clean glass rod. The samples were then allowed to settle for about 10 minutes and then continually stirred for about 15 minutes using a magnetic stirrer on a magnetic sitter plate. The samples were allowed to settle and their $\mathrm{pH}$ determined using the same calibrated instrument just as in the wastewater sample case.

\subsubsection{Water sample preparation and $\mathrm{pH}$ determination}

Two replicates each from WS 1 and WS 2 samples were digested by drawing $100 \mathrm{~mL}$ of each replicate into a beaker, to which $25 \mathrm{~mL}$ mixture of $3: 2$ conc. $\mathrm{HNO}_{3}$ and conc. $\mathrm{HCl}$ were added and the solution digested in a fume chamber for about 20 minutes. For efficient digestion of the water samples, additional $10 \mathrm{~mL}$ of conc. $\mathrm{HCl}$ were added and heated again in the fume chamber for about 15 minutes. Upon cooling, further filtration was carried out. Distilled water was added to the filtrate and made up to the 100 $\mathrm{mL}$ mark.

For each soil/water sample, calibration curves were prepared using heavy metal standards: $0.50,1.00$, 2.00 and $4.00 \mathrm{mg} \mathrm{L}^{-1}$ standards were each prepared in the spectrophotometric quantification of $\mathrm{Cr}$, $\mathrm{Cu}$ and $\mathrm{Pb}$ while calibration curves of concentrations $0.10,0.20,0.40$ and $0.80 \mathrm{mg} \mathrm{L}^{-1}$ were prepared in the case of $\mathrm{Cd}$. For each soil/water sample, duplicate analyses were performed using Perkin Elmer 400 Atomic Absorption Spectrophotometer (AAS) with air-acetylene gas serving as fuel for the flame. Where concentrations were very high, serial dilutions were performed on the samples and thereafter their dilution factors factored in the determination of their concentrations. All the results from soil and wastewater analyses were compared to Ghana Environmental Protection (EPA), World Health Organization (WHO), Food and Agricultural Organization (FAO) permissible limits.

\subsection{Indices for determination of soil pollution}

Three pollution indices were employed to evaluate the pollution levels of the four heavy metals in the scrapyard and its environs.

\subsubsection{Geoaccumulation Index (Igeo)}


Igeo determines the contamination of heavy metals by assessing their concentrations in sampled soils relative to background concentrations during pre-industrial periods $[17,18]$. Igeo is computed using the mathematical formula given as follows:

$\operatorname{lgeo}=\log 2(\mathrm{Cn} / 1.5 \mathrm{Bn})(1)$

where $\mathrm{Cn}$ is a measure of the heavy metal levels in the sediment under investigation while Bn represents the geochemical background level [18]. The constant 1.5 is used to lessen possible variations in the background data. In this study the four soil control sites were used as the geochemical background information by computing their expected values. Soils can be categorized into seven quality grades of pollution, as follows: Practically unpolluted, where $I_{\text {geo }}<0$; unpolluted to moderately polluted where $I_{\text {geo }}=$ $0-1$; moderately polluted where $\mathrm{I}_{\text {geo }}=1-2$; moderately to strongly polluted where $\mathrm{I}_{\text {geo }}=2-3$; strongly polluted where $\mathrm{I}_{\text {geo }}=3-4$; strongly to extremely polluted where $\mathrm{I}_{\text {geo }}=4-5$ and extremely polluted where $\mathrm{I}_{\text {geo }}$ $>5[18,19]$.

\subsubsection{Contamination Factor (CF)}

CF evaluates quantities of an element in a sample normalized over that of pre- industrial baseline value for the element. Mathematically, CF [20] is expressed as

$$
\mathrm{CF}=\mathrm{Ce} / \mathrm{Ci}(2)
$$

where $\mathrm{Ce}$ and $\mathrm{Ci}$ are respectively the concentration levels of the heavy metal in the sample of interest and the background value of the heavy metal of interest. Based on values obtained, soil or sediments can be classified as follows: no or low contamination where $\mathrm{CF}<1$; moderate contamination where $1<\mathrm{CF}<3$; considerable contamination where $3<\mathrm{CF}<6$; very high contamination where $\mathrm{CF}>6$ [21].

\subsubsection{Pollution Load Index (PLI)}

PLI [20] examines the mutual contribution of a group of metals to the pollution of a site. Mathematically, $\mathrm{PLI}=\left(\mathrm{CF}_{1} \times \mathrm{CF}_{2} \times \mathrm{CF}_{3} \times \mathrm{CF}_{4} \times \mathrm{CF}_{5} \times \ldots . \mathrm{CF}_{\mathrm{n}}\right)^{\wedge} 1 / \mathrm{n} \ldots \ldots .(3)$

where CF represents the contamination factor of each heavy metal element in a sampled soil and $\mathrm{n}$ is the number of heavy metals under consideration. The PLI gives an indication of whether the site under consideration is: lightly polluted, where $\mathrm{PLI} \leq 1$; moderately polluted, where $1<\mathrm{PLI} \leq 3$; highly polluted, where PLI > $3[21,22]$.

\subsection{Statistical analysis}

Means of the heavy meatal concentrations were computed and compared to reference values. The associated standard deviations were computed to determine the distributions of the metals. Differences in means were analyzed using t-test at $95 \%$ confidence level. These parameters were computed using Microsoft Excel software 2016 version. The relationships among the metals in the topsoil and subsoil at 
sites $\mathrm{H}$ and $\mathrm{F}$ were quantified using Pearson correlations. Coefficient of variations (CVs) of the heavy metal concentrations were computed to determine the source of pollution, using by SPSS version 21.0.

\section{Results And Discussion}

\subsection{Soil $\mathrm{pH}$ and heavy metal accumulation}

\subsubsection{Soil $\mathrm{pH}$}

Table 1 displays the permissible levels of metals in soil and water by Ghana EPA, WHO/FAO, whereas Tables 2-3 present $\mathrm{pH}$ and the four heavy metal concentrations at Sites Fand $\mathrm{H}$. pH values ranged from mild acidic to high alkaline conditions (5.88-8.03) with an average of 7.13 at for Site $F$ (Table 2). At site $\mathrm{H}$ (Table 3), pH ranged from 6.07 to 7.78 , with a mean of 6.94 . Heavy metal adsorption and retention by soil increases generally occur within a $\mathrm{pH}$ range of $4-7[23,24]$, thus the $\mathrm{pH}$ range could partly account for the elevated levels of heavy metals in the samples. $\mathrm{pH}$ values recorded were within the WHO benchmark of 6.5-8.5, except for three samples (5.88 at Site $F$ and $6.07,6.38$ at site $H$ ), where $\mathrm{pH}$ values were below the 6.5 minimum threshold. Relatively high pH value recorded in sample 5B (8.03) could be due to the presence of alkaline batteries, steel mill, and ashes from the incineration processes at the E-waste site.

\subsubsection{Heavy metal concentration}

Several factors, such as electron activity, soil texture, soil pH, ionic strength and level of organic matter, affect the metallic forms in soil matrix. Cd was found to be the least in concentration among the heavy metals in the two soil profiles at site $F$, from non-detection levels to a maximum of $1.57 \mathrm{ppm}$ and an average concentration of $0.48 \mathrm{ppm}$ (Table 2). With the exception of one sub-soil sample with a concentration of $1.57 \mathrm{ppm}$, all Cd concentrations at Site F were below the Ghana EPA permissible limit of $1 \mathrm{ppm}$ and the WHO/FAO standard of $3 \mathrm{ppm}$ (Tables 1-2). Cd mobility is dependent on several factors such $\mathrm{pH}$ and presence of organic matter that has strong affinity for the metal. The mean $\mathrm{pH}$ at this site was alkaline (7.13), which limits its availability, thus accounting for its low concentrations at this site [25, 26-28]. At site $\mathrm{H}, \mathrm{Cd}$ concentrations were relatively higher, with a minimum of $0.29 \mathrm{ppm}$ and a maximum of $13.56 \mathrm{ppm}$ and an average concentration of $4.14 \mathrm{ppm}$, which exceeds both Ghana EPA and the WHO/FAO standards (Tables 1 and 3). At this site, the mean pH was 6.94. The slightly acidic conditions may have contributed to the high levels of the metal. E-waste materials with $\mathrm{Cd}$ at the scrapyard include printed circuit boards, batteries, accumulators, cathode ray tubes and ultraviolet lights. Site $\mathrm{H}$ had higher concentrations of $\mathrm{Cd}$ than Site $\mathrm{F}$ because $\mathrm{Cd}$-containing E-waste materials were located more at the former site than the latter.

The minimum and maximum concentrations recorded at site $\mathrm{F}$ for $\mathrm{Cr}$ ranged from 13.97 to $162.50 \mathrm{ppm}$ with an average concentration of $77.33 \mathrm{ppm}$. Most $\mathrm{Cr}$ concentrations exceeded the Ghana EPA threshold value of $30 \mathrm{ppm}$ (Tables 1-2). Three samples also had $\mathrm{Cr}$ concentrations $(123.07,162.50$ and 117.27 $\mathrm{ppm}$ ) above the WHO/FAO standard of $100 \mathrm{ppm}$. However, Cr levels obtained in samples from site $\mathrm{H}$ were below the permissible limit of WHO/FAO and Ghana EPA with minimum and maximum concentrations of 
15.95 and $30.11 \mathrm{ppm}$, respectively and an average of $21.00 \mathrm{ppm}$ (Tables 1 and 3 ). Comparatively, $\mathrm{Cr}$ concentrations at site $\mathrm{F}$ were higher than those at site $\mathrm{H}$, which could be due to the fact that the metal containers that house E-waste materials were closer to site F. They are typically composed of steel and chromium, so any wear and tear on the metal adds on $\mathrm{Cr}$ concentrations to the soil, $\mathrm{pH}$ also being a factor.

At site $\mathrm{F}$ (Table 2), the minimum and maximum concentrations recorded for Cu were 29.97 and 253.42 ppm, respectively, with an average concentration of $114.85 \mathrm{ppm}$. The concentrations exceeded permissible levels of Ghana EPA (20 ppm) and the WHO/FAO standards of $100 \mathrm{ppm}$ (Table 1). Also, the minimum and maximum concentrations of $\mathrm{Cu}$ at site $\mathrm{H}$ ranged from 5.24 to108.76 ppm with an average concentration of $48.37 \mathrm{ppm}$, which were above the national and international limits (Tables 1 and 3 ). $\mathrm{Cu}$ finds application in most electrical and electronic appliances, such as printed circuit boards, cathode ray tubes, bare/insulated wires and in refrigeration units. Majority of the samples had high levels of $\mathrm{Cu}$ in the topsoil than the subsoil. These may be attributable to the strong binding between $\mathrm{Cu}$ and organic matter and minerals in the soil. Consequently, its mobility is supressed, and hence cannot be leached into the subsoil $[29,30]$. Also, the prevailing alkaline conditions in the topsoil played a critical role (Table 3 ).

Ranging from 13.58 to $276.78 \mathrm{ppm}$, with an average concentration of $77.07 \mathrm{ppm}$, at site $\mathrm{F}$, $\mathrm{Pb}$ level was found to have exceeded the WHO/FAO and Ghana EPA standard of 50 and 20 ppm, respectively (Tables 1-2). Elevated levels were detected for $\mathrm{Pb}$, ranging from 17.81 to $1000.85 \mathrm{ppm}$, with an average concentration of $341.43 \mathrm{ppm}$ at site $\mathrm{H}$, with so obvious exceedance (Tables 1 and 3 ). The lowest and the highest levels were all detected on the topsoil. E-waste materials with $\mathrm{Pb}$ include cathode ray tubes, fluorescent bulbs, batteries and fuses. The elevated $\mathrm{Pb}$ levels from site $\mathrm{F}$ to $\mathrm{H}$ is reflective of low organic matter in the presence of slightly alkaline to near-neutral mean soil $\mathrm{pH}$. It is contemplated that the elevated levels of $\mathrm{Pb}$ is a consequence of metal accumulation arising for all the operational years of the scrapyard. The extent of pollution at site $\mathrm{F}$ and $\mathrm{H}$ can be respectively expressed as follows: $\mathrm{Cu}>\mathrm{Cr}>\mathrm{Pb}>$ $\mathrm{Cd}$ and $\mathrm{Pb}>\mathrm{Cu}>\mathrm{Cr}>\mathrm{Cd}$.

Heavy metals concentrations in this study were similar to other E-waste research [4,31, 32]. Generally, $\mathrm{Cu}$ and $\mathrm{Pb}$ were in high concentrations in most of the research studies, suggesting an extensive use of the two metals in electrical appliances, whereas $\mathrm{Cd}$ concentrations seem to be on the lower side in most $\mathrm{E}$ waste soils in other research works (e.g., Table 4).

\subsection{Statistical Studies}

Tables 5a-g present the relationships between the metal levels at the following sampling sites: (i) Topsoil at site F, (ii) Subsoil at F, (iii) Topsoil at site H, (iv) Subsoil at site H, (v) Topsoil at F and H, (vi) Subsoil at F and $\mathrm{H}$, and (vii) Topsoil and subsoil over the scrapyard. These were quantified using Pearson correlation coefficient metric $r$.

The following were the key findings at the following sampling sites: (i) In the topsoil at site F, only Cd and Cu were significant, but exhibited out-of-phase relation ( $r=0.667 ; p<0.01$; Table $5 a)$; (ii) In the subsoil at 
site $\mathrm{F}$ (Table $5 b$ ), $\mathrm{Cu}, \mathrm{Cd}$, and $\mathrm{Pb}$ all exhibited in-phase relationships ( $\mathrm{Cu}$ vs. $\mathrm{Cd} r=0.926 ; \mathrm{p}<0.01 ; \mathrm{Pb}$ vs $\mathrm{Cd}$ $r=0.956 ; p<0.05 ; \mathrm{Pb}$ vs. Cu r=0.889; $p<0.05)$;

In the topsoil at site $\mathrm{H}$ (Table $5 \mathrm{c}$ ), it is only $\mathrm{Pb}$ and $\mathrm{Cu}$ that were significant and exhibited an in-phase relationship $(r=0.675 ; p<0.01)$. In the subsoil at site $\mathrm{H}$ (Table $5 d), \mathrm{Cr}, \mathrm{Cd}$, and $\mathrm{Cu}$ showed significant inphase relationships (Crvs. Cd r=0.786; $p<0.01$; Cu vs. $C d r=0.978 ; p<0.05 ;$ and $C u$ vs. $C r, r=0.653 ; p<0.01$ ).

In the topsoil at $\mathrm{F}$ and $\mathrm{H}$ (Table $5 \mathrm{e}$ ), $\mathrm{Cd}, \mathrm{Cr}$ and $\mathrm{Cu}$ at site $\mathrm{F}$, and $\mathrm{Cr}$ and $\mathrm{Pb}$ at site $\mathrm{H}$, showed good correlations. The in-phase relationship ranged from $r=0.693$ to $0.779 ; p<0.05$ and $p<0.01$ ). These were captured for Pb vs. Cr, Crvs. Cd, and Cd vs Cu. In contrast, $\mathrm{Cd}$ vs. $\mathrm{Cr}(\mathrm{r}=-770 ; \mathrm{p}<0.01)$ showed an out-ofphase relationship. Across the scrapyard, in the study area (Table $5 \mathrm{~g}$ ), the topsoil and subsoil revealed inphase relationship for $\mathrm{Cr}$ vs. $\mathrm{Cr}(\mathrm{r}=0.821 ; \mathrm{p}<0.05), \mathrm{Pb}$ vs $\mathrm{Cd}(\mathrm{r}=0.734 ; \mathrm{p}<0.01)$ and $\mathrm{Pb}$ vs. $\mathrm{Pb}(\mathrm{r}=0.79$; $\mathrm{p}<0.05)$.

From these results, it has been revealed that the in-phase relationships dominate the relationships and suggest synchronization of activities and chemical processes emanating from human E-waste recycling activities, whereas the out-of-phase relationships suggest otherwise. For instance, the in-phase relationships observed between pairs of heavy metals may be due to the dual complementary usage they have in certain EEE products. $\mathrm{Cd}$ and $\mathrm{Pb}$ find close applications in cathode ray tubes where $\mathrm{Cd}$ is used as the fluorescent powder coatings to produce color while $\mathrm{Pb}$ is employed to absorb the UV lights and X-rays produced. Cd is added to $\mathrm{Cu}$ to form alloys in Cd-Cu wire which are more resistant to softening at higher temperatures. $\mathrm{Pb}$ is also alloyed to $\mathrm{Cu}$ to act as a lubricant and also assist in chip break up, thereby increasing the machinability of the $\mathrm{Cu}$ metal. Since site $\mathrm{H}$ is used as a burning site and dumping grounds for burnt E-waste products, heavy metals may be carried from site $\mathrm{F}$ to site $\mathrm{H}$. This could explain the positive correlation between heavy metals at different site.

A coefficient of variation (CV) analysis carried out to determine if the presence of the heavy metals was due to natural or anthropogenic source showed CV for Cd, $\mathrm{Cr}, \mathrm{Cu}$ and $\mathrm{Pb}$ to be 137, 58, 61 and 104\%, respectively at site $\mathrm{F}$, and $108,22,125$ and $93 \%$ for $\mathrm{Cd}, \mathrm{Cr}, \mathrm{Cu}$ and $\mathrm{Pb}$, respectively at site $\mathrm{H}$. According to Guo et al. [33], a CV less than $20 \%$ indicates natural sources while values greater than $50 \%$ imply anthropogenic sources. By inference the heavy metal pollutions were due to anthropogenic sources, specifically E-waste activities.

An independent t-test analyses showed statistically significant differences in mean concentrations of the heavy metals, which are as follows:

1. significant difference between $C d$ concentrations at site $F($ Mean $(M)=0.39$, Standard deviation $(S D)=0.53)$ and $C d$ concentrations at site $H(M=4.14, S D=4.46)$, with a t-value of -2.50 and $p$-value of 0.02 (data are not normally distributed; skewed).

2. significant difference between $\mathrm{Cr}$ concentrations at site $\mathrm{F}(\mathrm{M}=77.33, \mathrm{SD}=44.57)$ and $\mathrm{Cr}$ concentrations at site $\mathrm{H}(\mathrm{M}=21.00, \mathrm{SD}=4.65)$, with a t-value of -3.98 and $p$-value of 0.001 (data are normally distributed). 
3. significant difference between $\mathrm{Cu}$ concentrations at site $\mathrm{F}(\mathrm{M}=114.85, \mathrm{SD}=70.33)$ and $\mathrm{Cu}$ concentrations at site $H(M=48.37, S D=6.58)$, with a t-value of 2.27 and $p$-value of 0.04 (data are normally distributed).

4. significant difference between $P b$ concentrations at site $F(M=77.07, S D=80.10)$ and $P b$ concentrations at site $\mathrm{H}(\mathrm{M}=341.43, \mathrm{SD}=317.96)$, with a t-value of -2.55 and $p$-value of 0.02 (data are not normally distributed; skewed for $\mathrm{Pb}$ at site $\mathrm{F}$ and normally distributed for same metal at site $\mathrm{H}$ ).

\subsection{Indices of pollution}

\subsubsection{Geoaccumulation Index}

Table 6 below shows $I_{\text {geo }}$ of sampled soil of the two sites. The $I_{\text {geo }}$ showed site $F$ was practically uncontaminated with $\mathrm{Cd}$ (average $\mathrm{I}_{\text {geo }}=-1.58$ ) and $\mathrm{Cr}$ (average $\mathrm{I}_{\text {geo }}=-1.07$ ) but unpolluted to moderately polluted with $\mathrm{Cu}$ (average $\mathrm{I}_{\text {geo }}=0.53$ ) and $\mathrm{Pb}$ (average $\mathrm{I}_{\text {geo }}=0.76$ ). At site $\mathrm{H}$, index of geoaccumulation showed a moderate to strong pollution with $\mathrm{Cd}$ (average $\left.\mathrm{I}_{\text {geo }}=2.16\right)$ and $\mathrm{Pb}$ (average $\left.\mathrm{I}_{\text {geo }}=2.64\right)$, a practically unpolluted soil with $\mathrm{Cr}$ (average $\mathrm{I}_{\text {geo }}=-2.72$ ), and $\mathrm{Cu}$ (average $\mathrm{I}_{\text {geo }}=-1.63$ ). Site $\mathrm{H}$ appears more contaminated than site $\mathrm{F}$, probably due to its dual role as a burning and dumping site for E-waste materials. $\mathrm{Pb}$ levels at site $\mathrm{H}$ for instance was in category 3 of the Igeo classification.

\subsubsection{Contamination Factor and Pollution Load Index}

Table 7 shows $\mathrm{CF}$ and PLI of the two sites. The CF showed site $\mathrm{F}$ had moderate contamination of $\mathrm{Cd}$ (average $\mathrm{CF}=1.30$ ) and $\mathrm{Cu}$ (average $\mathrm{CF}=2.55$ ), low contamination of $\mathrm{Cr}$ (average $\mathrm{CF}=0.86$ ), and considerable contamination of $\mathrm{Pb}$ (average $\mathrm{CF}=3.85$ ). At site $\mathrm{H}, \mathrm{CF}$ showed very high contamination of the soil with $\mathrm{Cd}$ (average $\mathrm{CF}=13.80$ ) and $\mathrm{Pb}$ (average $\mathrm{CF}=17.07$ ), no or low contamination of the soil with $\mathrm{Cr}$ (average $\mathrm{CF}=0.24$ ), moderately contaminated soil with $\mathrm{Cu}$ (average $\mathrm{CF}=1.08$ ). Again, results show more contamination of Site $\mathrm{H}$ than Site $\mathrm{F}$, possibly because of the dumping activities in addition to the open burning. PLI of both sites were found to be moderately polluted, with averages of 1.47 and 2.16 at sites $\mathrm{F}$ and $\mathrm{H}$, respectively.

\subsection{Spatial distribution of heavy metals}

Figures 2-4 show spatial distribution patterns of the heavy metals at the two sites, which were analyzed using the Inverse Distance Weighted (IDW) interpolation method. The analysis revealed elevated levels of heavy metals in subsoil ( $\mathrm{Cd}, \mathrm{Pb}$ at site $\mathrm{H}$ and $\mathrm{Cr}$, $\mathrm{Cu}$ at site $\mathrm{F}$ ), which indicates a possible leaching from the surface soil. The distribution pattern showed $\mathrm{Cu}$ retained more at the topsoil of site $\mathrm{F}$ and the northern section of site $\mathrm{H}$, indicating high presence of organic matter. Spatial maps also revealed site $\mathrm{H}$ was polluted more with $\mathrm{Pb}$ and $\mathrm{Cd}$ while site $\mathrm{F}$ was polluted with mostly $\mathrm{Cr}$ and $\mathrm{Cu}$.

\subsection{Concentration differences at increasing distance from scrapyard}


Figure 8 depicts the metal concentrations as a function of distance away from the scrapyard. Soil samples taken at 25, 50, 75 and $100 \mathrm{~m}$ away from the scrapyard were mostly sandy. $\mathrm{pH}$ values were mildly acidic, decreasing with distance away from the scrapyard, but within the WHO 6.5-8.5 thresholds. This is expected, as increasing distance from the scrapyard means decreasing heavy metals concentrations, which are mostly alkaline. This finding is comparable to a study by [34] where the $\mathrm{pH}$ at a dumpsite decreased from 5.9 to 4.7 at a distance of $18 \mathrm{~m}$ from the dumpsite.

The results practically revealed no $\mathrm{Cd}$ in these soil samples. Samples taken within the $25 \mathrm{~m}$ distance were found to contain respective concentrations of 20.73, 24.94 ppm for $\mathrm{Cr}$ and $\mathrm{Cu}$ and were within safe levels set by WHO/FAO but slightly above permissible levels of Ghana EPA with respect to Cu. However, $\mathrm{Pb}$ recorded a concentration of $155.17 \mathrm{ppm}$ which exceeds the safe levels of $\mathrm{Pb}$ in soil as determined by both WHO/FAO and Ghana EPA. pH of the soil sample at $25 \mathrm{~m}$ was almost neutral at 6.97.

The levels of $\mathrm{Cr}$ and $\mathrm{Cu}$ in soil samples within the $50 \mathrm{~m}$ boundary were again within the safe limits set by WHO/FAO, but above permissible levels of Ghana EPA, with respective concentrations of 25.18 and 96.73 ppm. $\mathrm{Pb}$ levels again exceeded the $50 \mathrm{ppm}$ threshold of WHO/FAO and the $20 \mathrm{ppm}$ threshold of Ghana EPA, reaching levels of $74.72 \mathrm{ppm}$. pH of the soil sample at $50 \mathrm{~m}$ was mildly acidic at 6.58 . Soil samples taken $75 \mathrm{~m}$ from the scrapyard had concentrations of $4.122 \mathrm{ppm}(\mathrm{Cr}), 4.600 \mathrm{ppm}(\mathrm{Cu})$ and $5.965 \mathrm{ppm}$ $\mathrm{Pb})$ while at a $100 \mathrm{~m}$ distance variation, soil samples analyzed revealed no levels of $\mathrm{Cr}, 1.260 \mathrm{ppm}$ of $\mathrm{Cu}$ and $8.970 \mathrm{ppm}$ of $\mathrm{Pb}$. It can be thus inferred that the activities at the scrapyard still have effect 25 to 50 $\mathrm{m}$ away from it. However, since soil samples taken at 25 and $50 \mathrm{~m}$ were close to the Accra - Tema motorway, contamination from road dust is still possible since heavy metals can be found in tires and brake abrasion, combustion exhaust and pavements wear [35], which can be transported by rain, runoff, dry deposition, and atmospheric drifts. and Further research will be needed to investigate this proposition.

With a general decline in the concentrations of heavy metals from the 75 and $100 \mathrm{~m}$ distance, the high levels of heavy metals within the scrap yard can be attributed mainly to that of the E-waste activities. Comparably, concentrations of $\mathrm{Cr}, \mathrm{Cu}$ and $\mathrm{Pb}$ were several times higher within the scrapyard than outside of it.

The decreasing concentrations of heavy metals with increasing distances from the scrapyard agrees with other research studies which explored the effect of increasing distance from source on concentration levels of heavy metals $[36,37]$.

\subsection{Heavy metal concentrations in sediment and water}

The metal concentrations in the drain both upstream and downstream are shown in Table 9. Soilsediment-water samples (WSC) taken outside the scrapyard showed lower concentration of heavy metals than those obtained within the scrapyard particularly at WS 1, while the four heavy metals were absent within the water at WS 2. Water sediment outside the scrapyard (WSC) was found to contain Cd and Cr, with respective concentrations of 0.03 and $11.95 \mathrm{ppm}$, whereas the levels of $\mathrm{Cu}$ and $\mathrm{Pb}$ were 5.84 and $5.89 \mathrm{ppm}$, respectively. Water sediments within the scrapyard (WS1) were found to contain $0.49 \mathrm{ppm} \mathrm{Cd}$, 
and a concentration of $217.98 \mathrm{ppm}$, for $\mathrm{Cu}$. $\mathrm{Cr}$ had a concentration of $12.28 \mathrm{ppm}$ while $\mathrm{Pb}$ had a concentration of $44.77 \mathrm{ppm}$. The levels of the toxic metals in the water sediments of WS1 increased significantly within the scrapyard as one moves downstream from WSC. With the wastewater drain lying in a lower plain to the two burning sites, and with movement of air current across the drain from the two burning sites, it can be fairly postulated that the E-waste activities are a possible origin for the heavy metals in the soil-sediment water samples, through the actions of wind drift and dry deposition. One other possibility is the presence of E-waste materials found near or inside the drain, causing heavy metals to dissolve into the wastewater as has been reported elsewhere [38].

The relatively concentrated amounts of heavy metals of soil-sediment-samples (WS1), compared to no detection in the surface wastewater samples at WS2 supports the research hypothesis, that heavy metals tend to be high in sediments and settleable particles than surface water [39]. WSC and WS1 samples had mild alkaline $\mathrm{pH}$, indicative of the presence of the heavy metals. Levels of heavy metals in the drain represented by WS1 were all above the standard permissible levels of Ghana EPA and WHO/FAO. This is of a major concern since the drain serves as irrigation source for farm crops as well as drinking water for herds of cattle near the scrapyard.

\section{Conclusions}

The research revealed soil and drainage system of the Ashaiman scrapyard were polluted with $\mathrm{Cu}, \mathrm{Pb}, \mathrm{Cr}$ and $\mathrm{Cd}$, mainly due to open burning and dumping of E-waste materials. The $\mathrm{CV}$ results indicate that the metal pollution is primarily anthropogenically driven. The research further showed levels of the heavy metals exceeded permissible limits of WHO/FAO (2011) and Ghana EPA. Igeo of soil samples from scrapyard ranged from practically unpolluted levels $(\mathrm{Cr}, \mathrm{Cd}$ and $\mathrm{Cu})$ to strongly polluted levels $(\mathrm{Pb})$. $\mathrm{CF}$ at scrapyard ranged from low contamination $(\mathrm{Cr})$ to a very high contamination ( $\mathrm{Cd}$ and $\mathrm{Pb}$ ) with a moderate PLI. Spatial distribution maps revealed pollution of the heavy metals, especially at the western north of site $\mathrm{H}$ and the central portion of site $\mathrm{F}$.

Consequently, environmental laws and regulations on management and recycling of E-wastes should be enforced by local authorities to prevent further contamination and pollution of the scrapyard and its environs. Public awareness and education on the adverse effect of informal recycling practices should be intensified.

The study has further shown that $\mathrm{Cd}$ levels (at sites $\mathrm{F}$ and $\mathrm{H}$ ) and $\mathrm{Pb}$ levels ( at site $\mathrm{F}$ ) in the scrapyard suggest skewed distributions relative to $\mathrm{Cr}$ and $\mathrm{CU}$ (at both sites) and $\mathrm{Pb}$ (at site $\mathrm{H}$ ), which are normally distributed. This outcome provides insight into modeling the behavior of these metals in future. Finally, future studies can also focus on investigation of heavy metals contamination in workers at the scrapyard and herds of cattle around the environment.

\section{Declarations}


Availability of data and materials

All data generated or analyzed during this study are included in this published article.

\section{Competing interests}

The authors declare there is no conflicting interest regarding this study.

\section{Funding}

The present study had no funding sources of any kind.

\section{Authors' contributions}

The corresponding author (Isaac Kow Tetteh) supervised the entire research $\llbracket$ conceptualization, synthesis of ideas, scope, experimental design, analysis framework, data interpretation, review and editing the manuscript. The first author (Albert Kwame Teye) performed the field and lab work as well as contributed to writing the manuscript. All authors read and approved the final manuscript.

\section{Acknowledgements}

The authors express appreciation to the workers of the Ashaiman scrapyard for their cooperation in carrying out this study. Our appreciation also goes to the laboratory staff of Ghana Standard Authority where the soil and water samples were analyzed.

\section{Authors' information}

Albert Kwame Teye and Isaac Kow Tetteh

Department of Environmental Science,

Kwame Nkrumah University of Science and Technology (KNUST),

Kumasi- Ghana

\section{References}

1. Baldé CP, Forti V, Gray V, Kuehr R, Stegmann P. The Global E-waste Monitor 2017: Quantities, Flows and Resources. Bonn/Geneva/Vienna: United Nations University; 2017.

2. Mmereki D, Li B, Baldwin A, Hong L. The generation, composition, collection, treatment and disposal system, and impact of e-waste. Rijeka: InTech; 2016.

3. Orisakwe OE, Frazzoli C, Llo CE, Oritsemuelebi B. Public health burden of e-waste in Africa. J Health Pollut. 2019;9:190610. 
4. Amoyaw-Osei Y, Agyekum OA, Pwamang JA, Mueller E, Fasko R, Schluep M. Ghana e-Waste Country Assessment. Accra: European Commission/Green Advocacy Ghana/Ghana EPA/Basel Convention/UNEP/Swiss Federal Laboratories for Material Science and Technology; 2011.

5. Brigden K, Labunska I, Santillo D, Johnston P. Chemical Contamination at E-waste Recycling and Disposal Sites in Accra and Koforidua, Ghana. Amsterdam: Greenpeace International; 2008.

6. Isimekhai KA. Environmental risk assessment for an informal e-waste recycling site in Lagos State, Nigeria [Ph.D. Dissertation]. London: Middlesex University London; 2017.

7. Dharini K, Bernadette JC, Kamalambikai B, Celestina J, Muthu D. Hazardous e-waste and its impact on soil structure. IOP Conf Ser: Earth Environ Sci. 2017;80:2-5.

8. Holloway PH. Gold/chromium metallizations for electronic device. Gold Bull. 1979;12:99-106.

9. Tchounwou PB, Yedjou CG, Patlolla AK, Sutton DJ. Heavy metal toxicity and the environment. 2012; 101:133-64.

10. Briffa, J, Sinagra E, Blundell R. 2020. Heavy metal pollution in the environment and their toxicological effects on humans. Heliyon. 2020;6:e04691

11. Pwamang JA. Government Policy and Initiatives on E-Waste in Ghana. In: 3rd Annual Global E-waste Management (GEM) Network Meeting. California; 2013 July 15-19.

12. Mariwah S, Osei K, Amenyo-Xa MS. Urban land use/land cover changes in the Tema metropolitan area (1990-2010). GeoJournal. 2017;82:247-58.

13. Okine HA. E-waste imports and management practices in Ghana: A case study of Accra-Tema Metropolitan Area [Masters Dissertation]. Accra: University of Ghana; 2014.

14. Wong C, Xiang-Dong L. Analysis of heavy metal contaminated soils. Pract Periodical Haz Toxic Radioactivation Waste Management. 2003;7:2-15.

15. Qiao P, Lei M, Yang S, Yang J, Guo G, Zhou X. Comparing ordinary kriging and inverse distance weighting for soil as pollution in Beijing. Environ Sci Pollut Res. 2018;25:15597-608.

16. Al-Busaidi A, Cookson P, Yamamoto T. Methods of $\mathrm{pH}$ determination in calcareous soils: Use of electrolytes and suspension effect. Aust J Soil Res. 2005;43:541-5.

17. Nowrouzi M, Pourkhabbaz A. Application of geoaccumulation index and enrichment factor for assessing metal contamination in the sediments of Hara Biosphere Reserve, Iran. Chem Speciat Bioavailab. 2014;26:99-105.

18. Varol M. Assessment of heavy metal contamination in sediments of the Tigris River (Turkey) using pollution indices and multivariate statistical techniques. J Hazard Mater. 2011;195:355-64.

19. Kalender L, Uçar SÇ. Assessment of metal contamination in sediments in the tributaries of the Euphrates River, using pollution indices and the determination of the pollution source, Turkey. $J$ Geochem Explor. 2013;134:73-84.

20. Özkan EY. A new assessment of heavy metal contaminations in an eutrophicated bay (Inner Izmir Bay, Turkey). Turkish J Fish Aquat Sci. 2012;12:135-47. 
21. Fosu-Mensah BY, Addae E, Yirenya-Tawiah D, Nyame F. Heavy metals concentration and distribution in soils and vegetation at Korle Lagoon area in Accra, Ghana. Cogent Environ Sci. 2017;3:1405887.

22. Chen TB, Zheng YM, Lei M, Huang ZC, Wu HT, Chen $H$, et al. Assessment of heavy metal pollution in surface soils of urban parks in Beijing, China. Chemosphere. 2005; 60:542-51.

23. Kerndorff H, Schnitzer M. Sorption of metals on humic acid. GCA. 1980;44:1701-8.

24. Sherene T. Mobility and transport of heavy metals in polluted soil environment. BFAIJ. 2010; 2:11221.

25. Elinder CG. Cadmium as an environmental hazard. IARC Sci Publ. 1992; 118:123-32.

26. Alloway BJ, Steinnes E. Anthropogenic additions of Cadmium to soils. 1st ed. Dordrecht: Springer Netherlands; 1999.

27. Kuo S, Heilman PE, Baker AS. Distribution and forms of copper, zinc, cadmium, iron, and manganese in soils near a copper smelter. Soil Sci. 1983; 135:101-9.

28. Wieczorek J, Baran A, Urbanski K, Mazurek R, Klimowicz-Pawlas A. Assessment of the pollution and ecological risk of lead and cadmium in soils. Environ Geochem Health. 2018;40:2325-42.

29. Alloway BJ. Soil processes and the behavior of metal. Glasgow: Blackie Academic Professional; 1990.

30. Kabata-Pendias A. Trace elements in soils and plants. 4th ed. Boca Raton: CRC Press; 2010.

31. Adesokan MD, Adie G, Osibanjo O. Soil pollution by toxic metals near e-waste recycling operations in Ibadan, Nigeria. J Health Pollut. 2016;6:26-33.

32. Ha NN, Agusa T, Ramu K, Tu NCT, Murata S, Bulbule KA, et al. Contamination by trace elements at ewaste recycling sites in Bangalore, India. Chemosphere. 2009; 76:9-15.

33. Guo G, Wu F, Xie F, Zhang R. Spatial distribution and pollution assessment of heavy metals in urban soils from southwest China. J Environ Sci. 2012;24:410-8.

34. Aisien FA, Okoduwa IG, Aisien ET. Levels of heavy metals in and around scrap car dumpsite at Uwelu, Nigeria.Curr J Appl Sci Technol. 2013;3:1519-22.

35. Radziemska M, Fronczyk J. Level and contamination assessment of soil along an expressway in an ecologically valuable area in Central Poland. Int J Environ Res Public Health. 2015; 12:13372-87.

36. Svendsen ML, Steinnes E, Blom HA. Vertical and horizontal distributions of $\mathrm{Zn}, \mathrm{Cd}, \mathrm{Pb}, \mathrm{Cu}$, and $\mathrm{Hg}$ in uncultivated soil in the vicinity of a zinc smelter at Odda, Norway. Soil Sediment Contam. 2007; 16:585-603.

37. Fujimori T, Takigami. H. Pollution distribution of heavy metals in surface soil at an informal electronic-waste recycling site. Environ Geochem Health. 2014;36:159-68.

38. Uchida N, Matsukami H, Someya M, Tue NM, Viet PH, Takahashi S, et al. Hazardous metals emissions from e-waste-processing sites in a village in northern Vietnam. Emerg Contam. 2018; 4: 11-21.

39. Radulescu C, Stihi C, Dulama LD, Chelarescu ED, Bretcan P, Tanislav D. Assessment of heavy metals content in water and mud of several salt lakes from Romania by atomic absorption spectrometry. 
Rom J Phys. 2015; 60: 246-56.

\section{Tables}

Table 1 Ghana EPA and WHO/FAO permissible levels of heavy metals in soil and water

\begin{tabular}{|c|c|c|c|c|}
\hline $\begin{array}{l}\text { Heavy } \\
\text { Metal }\end{array}$ & $\begin{array}{l}\text { EPA Ghana Limit } \\
\text { in soil } \\
\text { (ppm) }\end{array}$ & $\begin{array}{l}\text { EPA } \\
\text { Ghana } \\
\text { Limit in } \\
\text { water } \\
\text { (ppm) }\end{array}$ & $\begin{array}{l}\text { WHO/FAO Limit } \\
\text { in soil } \\
\text { (ppm) }\end{array}$ & $\begin{array}{l}\text { WHO/FAO Limit in water } \\
\text { (ppm) }\end{array}$ \\
\hline $\mathrm{Cd}$ & 1 & - & 3 & 0.01 \\
\hline $\mathrm{Cr}$ & 30 & 0.1 & 100 & 0.1 \\
\hline $\mathrm{Cu}$ & 20 & - & 100 & 0.2 \\
\hline $\mathrm{Pb}$ & 20 & 0.1 & 50 & 5 \\
\hline
\end{tabular}

Table 2 Concentration and $\mathrm{pH}$ of soil samples at site $\mathrm{F}$ 


\begin{tabular}{|c|c|c|c|c|c|c|c|}
\hline $\begin{array}{l}\text { Site } \\
\text { /Sample }\end{array}$ & Latitude & Longitude & $\begin{array}{l}\text { Conc } \\
\text { (ppm }\end{array}$ & ation & selected & avy metals & $\mathrm{pH}$ \\
\hline $\mathbf{F}$ & & & $\mathrm{Cd}$ & $\mathrm{Cr}$ & $\mathrm{Cu}$ & $\mathrm{Pb}$ & \\
\hline $1 \mathrm{~A}$ & $5.682713 \mathrm{~N}$ & $0.029065 \mathrm{~W}$ & 0.92 & 73.02 & 82.60 & 99.63 & 7.36 \\
\hline $1 B$ & $5.682713 \mathrm{~N}$ & $0.029065 \mathrm{~W}$ & n.d & 123.07 & 70.74 & 13.58 & 7.14 \\
\hline $2 \mathrm{~A}$ & $5.682441 \mathrm{~N}$ & $0.029085 \mathrm{~W}$ & 0.05 & 49.08 & 129.37 & 276.78 & 6.86 \\
\hline 2B & $5.682441 \mathrm{~N}$ & $0.029085 \mathrm{~W}$ & 0.03 & 13.97 & 29.97 & 38.73 & 5.88 \\
\hline $3 A$ & $5.682558 \mathrm{~N}$ & $0.028997 \mathrm{~W}$ & 0.17 & 162.50 & 122.30 & 83.48 & 6.80 \\
\hline 3B & $5.682558 \mathrm{~N}$ & $0.028997 \mathrm{~W}$ & 0.12 & 117.27 & 92.22 & 14.10 & 7.35 \\
\hline $4 \mathrm{~A}$ & $5.682700 \mathrm{~N}$ & $0.028879 W$ & 0.11 & 60.81 & 219.82 & 32.97 & 7.38 \\
\hline $4 B$ & $5.682700 \mathrm{~N}$ & $0.028879 \mathrm{~W}$ & 0.02 & 36.37 & 73.64 & 40.25 & 7.46 \\
\hline $5 \mathrm{~A}$ & $5.682575 \mathrm{~N}$ & $0.029130 \mathrm{~W}$ & 0.52 & 67.49 & 74.42 & 38.75 & 7.04 \\
\hline $5 B$ & $5.682575 \mathrm{~N}$ & $0.029130 \mathrm{~W}$ & 1.57 & 69.74 & 253.42 & 132.45 & 8.03 \\
\hline MEAN & & & 0.39 & 77.33 & 114.85 & 77.07 & 7.13 \\
\hline MIN & & & 0.02 & 13.97 & 29.97 & 13.58 & 5.88 \\
\hline MAX & & & 1.57 & 162.50 & 253.42 & 276.78 & 8.03 \\
\hline STD.V & & & 0.53 & 44.57 & 70.34 & 80.10 & 0.56 \\
\hline
\end{tabular}

n. d................. not detected

Table 3 Concentration and $\mathrm{pH}$ of soil samples at site $\mathrm{H}$ 


\begin{tabular}{|c|c|c|c|c|c|c|c|}
\hline Site /Sample & Latitude & Longitude & Conce & ration & Heavy I & tals (ppm) & $\mathrm{pH}$ \\
\hline $\mathbf{H}$ & & & $\mathrm{Cd}$ & $\mathrm{Cr}$ & $\mathrm{Cu}$ & $\mathrm{Pb}$ & \\
\hline $1 \mathrm{~A}$ & $5.683217 \mathrm{~N}$ & $0.029051 \mathrm{~W}$ & 0.29 & 17.11 & 108.76 & 84.29 & 7.78 \\
\hline $1 \mathrm{~B}$ & $5.683217 \mathrm{~N}$ & $0.029051 \mathrm{~W}$ & 0.34 & 15.40 & 7.07 & 59.43 & 6.58 \\
\hline $2 \mathrm{~A}$ & $5.683190 \mathrm{~N}$ & $0.028980 \mathrm{~W}$ & 1.67 & 30.11 & 5.24 & 300.25 & 6.91 \\
\hline $2 B$ & $5.683190 \mathrm{~N}$ & $0.028980 \mathrm{~W}$ & 1.05 & 15.95 & 10.76 & 514.80 & 7.09 \\
\hline $3 A$ & $5.683153 \mathrm{~N}$ & $0.028938 \mathrm{~W}$ & 13.56 & 25.25 & 12.40 & 17.81 & 7.38 \\
\hline 3B & $5.683153 \mathrm{~N}$ & $0.028938 \mathrm{~W}$ & 2.34 & 22.32 & 14.05 & 46.61 & 7.44 \\
\hline $4 \mathrm{~A}$ & $5.683145 \mathrm{~N}$ & $0.029027 \mathrm{~W}$ & 6.87 & 21.11 & 48.00 & 572.79 & 6.50 \\
\hline $4 B$ & $5.683145 \mathrm{~N}$ & $0.029027 \mathrm{~W}$ & 0.53 & 17.31 & 6.85 & 261.26 & 6.07 \\
\hline $5 \mathrm{~A}$ & $5.683328 \mathrm{~N}$ & $0.028788 \mathrm{~W}$ & 7.96 & 23.10 & 185.77 & 1000.85 & 7.24 \\
\hline $5 B$ & $5.683328 \mathrm{~N}$ & $0.028788 \mathrm{~W}$ & 6.79 & 22.32 & 84.76 & 556.20 & 6.38 \\
\hline MEAN & & & 4.14 & 21.00 & 48.37 & 341.41 & 6.94 \\
\hline MIN & & & 0.29 & 15.40 & 5.24 & 17.81 & 6.07 \\
\hline MAX & & & 13.56 & 30.11 & 185.77 & 1000.85 & 7.78 \\
\hline STD.V & & & 4.46 & 4.65 & 60.58 & 317.96 & 0.54 \\
\hline
\end{tabular}

Jle 4 Review of research studies on heavy metals concentrations (ppm) in E-waste

\begin{tabular}{llllll}
\hline ss & $\mathrm{Cd}$ & $\mathrm{Cr}$ & $\mathrm{Cu}$ & $\mathrm{Pb}$ & Reference \\
\hline lan, Nigeria & $2.50 \pm 0.08$ & $42.4 \pm 2.6$ & $3483 \pm 980$ & $5650 \pm 750$ & {$[40]$} \\
\hline sridua, Ghana & 3 & 47 & 14300 & 3530 & {$[6]$} \\
galore, India & 0.478 & 54 & 429 & 126 & {$[41]$} \\
\hline ling, China & 3 & 101.29 & 180.66 & 187.30 & {$[42]$} \\
\hline aiman, Ghana & 7.96 & 23.10 & 185.77 & 1000.85 & Current research \\
\hline
\end{tabular}


Table 5a Correlation of soil heavy metal concentrations in topsoil at site $\mathrm{F}$

\begin{tabular}{l|llll} 
& $C d$ & $C r$ & $C u$ & $P b$ \\
\hline$C d$ & 1 & & & \\
$C r$ & -.105 & 1 & & \\
$C u$ & $-.667^{b}$ & -.119 & 1 & \\
$P b$ & -.314 & -.268 & -.106 & 1
\end{tabular}

${ }^{\mathrm{b}}$ Significant correlation at the 0.01 level (2-tailed).

Table $5 \mathrm{~b}$ Correlation of heavy metal concentrations in subsoil at site $\mathrm{F}$

\begin{tabular}{l|llll} 
& $C d$ & $C r$ & $C u$ & $P b$ \\
\hline$C d$ & 1 & & & \\
$C r$ & -.155 & 1 & & \\
$C u$ & $.926^{\mathrm{b}}$ & .168 & 1 & \\
$P b$ & $.956^{\mathrm{a}}$ & -.282 & $.889^{\mathrm{a}}$ & 1
\end{tabular}

a Significant correlation at the 0.05 level (2-tailed).

${ }^{\text {b}}$ Significant correlation at the 0.01 level (2-tailed).

Table 5c Correlation of heavy metal concentrations in topsoil at site $\mathrm{H}$

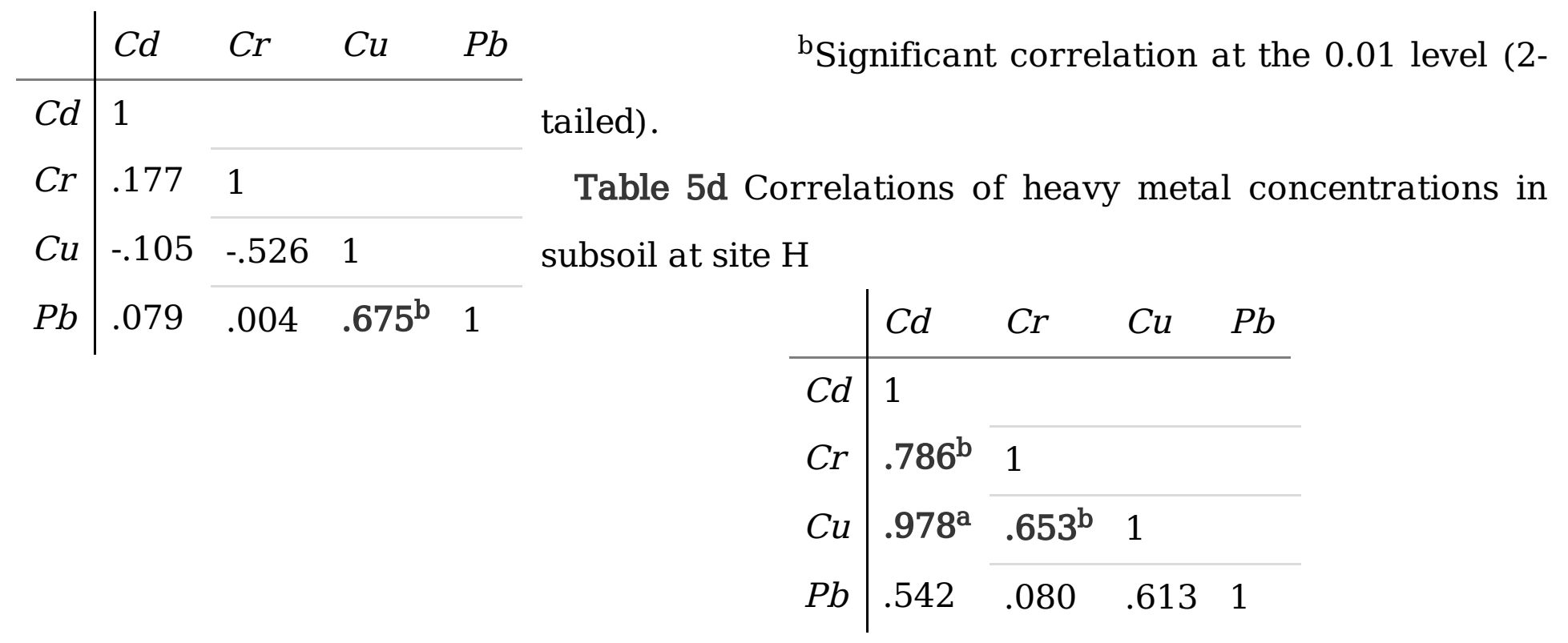

aSignificant correlation at the 0.05 level (2-tailed).

bignificant correlation at the 0.01 level (2-tailed). 
Table 5e Correlations of heavy metal concentrations at topsoil at sites $\mathrm{F}$ and $\mathrm{H}$

\begin{tabular}{l|llll}
$H / F$ & $C d$ & $C r$ & $C u$ & $P b$ \\
\hline$C d$ & -.405 & $-.770^{\mathrm{a}}$ & $.700^{\mathrm{b}}$ & -.029 \\
$\mathrm{Cr}$ & $.779^{\mathrm{a}}$ & .043 & -.295 & -.505 \\
$\mathrm{Cu}$ & .151 & .080 & -.556 & .000 \\
$\mathrm{~Pb}$ & -.505 & $.693^{\mathrm{a}}$ & -.538 & -.372
\end{tabular}

asignificant correlation at the 0.05 level (2-tailed).

Table 5 f Correlations of heavy metal concentrations in subsoil at sites $\mathrm{F}$ and $\mathrm{H}$

\begin{tabular}{l|llll}
$H / F$ & $C d$ & $C r$ & $C u$ & $P b$ \\
\hline$C d$ & $.973^{\mathrm{a}}$ & $.723^{\mathrm{b}}$ & $.970^{\mathrm{a}}$ & $.673^{\mathrm{b}}$ \\
$C r$ & .530 & .298 & $-.011^{-.758^{\mathrm{b}}}$ \\
$C u$ & $.951^{\mathrm{a}}$ & $.723^{\mathrm{b}}$ & $.965^{\mathrm{a}}$ & .412 \\
$P b$ & $.896^{\mathrm{a}}$ & .497 & $.954^{\mathrm{a}}$ & $.775^{\mathrm{b}}$
\end{tabular}

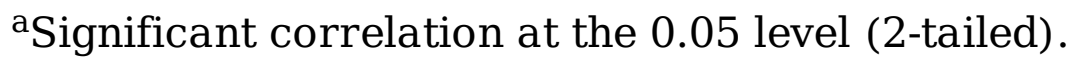

${ }^{\mathrm{b}}$ Significant correlation at the 0.01 level (2-tailed).

Table $5 \mathrm{~g}$ Correlations of heavy metal concentrations in the topsoil and subsoil over the scrapyard

\begin{tabular}{l|llll} 
Topsoil/subsoil & $C d$ & $C r$ & $C u$ & $P b$ \\
\hline$C d$ & .585 & -.364 & -.291 & .279 \\
$C r$ & -.351 & .821 & .410 & -.444 \\
$C u$ & .181 & .062 & .203 & -.105 \\
$P b$ & $.734^{\mathrm{b}}$ & -.372 & -.157 & $.791^{\mathrm{a}}$
\end{tabular}

asignificant correlation at the 0.05 level (2-tailed).

${ }^{\mathrm{b}}$ Significant correlation at the 0.01 level (2-tailed).

Table 6 Igeo of four heavy metals at sampled sites 


\section{il sample Igeo of heavy metals}

\begin{tabular}{lllllllll}
\hline & Site $\mathrm{F}$ & \multicolumn{7}{c}{ Site $\mathrm{H}$} \\
\hline & $\mathrm{Pb}$ & $\mathrm{Cu}$ & $\mathrm{Cr}$ & $\mathrm{Cd}$ & $\mathrm{Pb}$ & $\mathrm{Cd}$ & $\mathrm{Cu}$ & $\mathrm{Cr}$ \\
\hline & 1.73 & 0.29 & -0.89 & 1.03 & 1.49 & -0.64 & 0.69 & -2.98 \\
\hline & -1.14 & 0.07 & -0.13 & $\mathrm{n} . \mathrm{d}$ & 0.99 & -0.39 & -3.26 & -3.13 \\
\hline & 3.21 & 0.94 & -1.46 & -3.24 & 3.32 & 1.89 & -3.69 & -2.17 \\
\hline & 0.37 & -1.17 & -3.27 & -3.99 & 4.10 & 1.22 & -2.65 & -3.08 \\
\hline & 1.48 & 0.86 & 0.27 & -1.39 & -0.75 & 4.91 & -2.45 & -2.42 \\
\hline & -1.09 & 0.45 & -0.20 & -1.86 & 0.64 & 2.38 & -2.26 & -2.60 \\
\hline & 0.14 & 1.70 & -1.15 & -2.01 & 4.26 & 3.93 & -0.49 & -2.68 \\
\hline \multirow{3}{*}{ ¿AN } & 0.42 & 0.13 & -1.89 & -4.76 & 3.12 & 0.23 & -3.30 & -2.96 \\
\hline & 0.37 & 0.14 & -1.00 & 0.22 & 5.06 & 4.15 & 1.46 & -2.55 \\
\hline & 2.14 & 1.91 & -0.95 & 1.81 & 4.21 & 3.92 & -0.33 & -2.60 \\
& 0.76 & 0.53 & -1.07 & -1.58 & 2.64 & 2.16 & -1.63 & -2.72 \\
\hline
\end{tabular}

Table 7 CF and PLI of the four heavy metals at sampled sites 
Site H

\begin{tabular}{|c|c|c|c|c|c|c|c|c|c|c|}
\hline & CF & & & & PLI & $\mathrm{CF}$ & & & & PLI \\
\hline & $\mathrm{Pb}$ & $\mathrm{Cu}$ & $\mathrm{Cd}$ & $\mathrm{Cr}$ & & $\mathrm{Pb}$ & $\mathrm{Cd}$ & $\mathrm{Cu}$ & $\mathrm{Cr}$ & \\
\hline & 4.98 & 1.84 & 3.06 & 0.81 & 2.18 & 4.22 & 0.96 & 2.42 & 0.19 & 1.17 \\
\hline & 0.68 & 1.57 & - & 1.37 & 1.36 & 2.97 & 1.14 & 0.16 & 0.17 & 0.55 \\
\hline & 13.8 & 2.88 & 0.16 & 0.55 & 1.36 & 15.01 & 5.55 & 0.12 & 0.34 & 1.34 \\
\hline & 1.94 & 0.67 & 0.09 & 0.16 & 0.37 & 25.74 & 3.50 & 0.24 & 0.18 & 1.40 \\
\hline & 4.17 & 2.72 & 0.57 & 1.81 & 1.85 & 0.89 & 45.22 & 0.28 & 0.28 & 1.33 \\
\hline & 0.71 & 2.05 & 0.42 & 1.30 & 0.94 & 2.33 & 7.80 & 0.31 & 0.25 & 1.09 \\
\hline & 1.65 & 4.89 & 0.37 & 0.68 & 1.19 & 28.64 & 22.91 & 1.07 & 0.24 & 3.58 \\
\hline & 2.01 & 1.64 & 0.06 & 0.40 & 0.52 & 13.06 & 1.75 & 0.15 & 0.19 & 0.91 \\
\hline & 1.94 & 1.65 & 1.75 & 0.75 & 1.43 & 50.04 & 26.54 & 4.13 & 0.26 & 6.13 \\
\hline & 6.62 & 5.63 & 5.25 & 0.78 & 3.51 & 27.81 & 22.64 & 1.88 & 0.25 & 4.14 \\
\hline AN & 3.85 & 2.55 & 1.30 & 0.86 & 1.47 & 17.07 & 13.80 & 1.08 & 0.24 & 2.16 \\
\hline
\end{tabular}

Table 8 Concentrations of heavy metals and $\mathrm{pH}$ at varying distance from scrapyard 


\begin{tabular}{|c|c|c|c|c|c|c|c|}
\hline \multirow[t]{2}{*}{ Sample } & \multirow[t]{2}{*}{ Latitude } & \multirow[t]{2}{*}{ Longitude } & \multicolumn{4}{|c|}{ Concentration of selected heavy metals (ppm) } & \multirow[t]{2}{*}{$\mathrm{pH}$} \\
\hline & & & $\mathrm{Cd}$ & $\mathrm{Cr}$ & $\mathrm{Cu}$ & $\mathrm{Pb}$ & \\
\hline HV 25 & $5.682392 \mathrm{~N}$ & $0.027973 W$ & n.d & 20.73 & 24.94 & 155.17 & 6.97 \\
\hline HV 50 & $5.682438 \mathrm{~N}$ & $0.027473 W$ & n.d & 25.18 & 96.73 & 74.72 & 6.58 \\
\hline HV 75 & $5.682677 \mathrm{~N}$ & $0.026773 \mathrm{~W}$ & n.d & 4.12 & 4.60 & 5.97 & 6.71 \\
\hline HV 100 & $5.6826190 \mathrm{~N}$ & $0.026582 \mathrm{~W}$ & n.d & n.d & 1.26 & 8.97 & 6.72 \\
\hline MEAN & & & & 16.68 & 31.88 & 61.21 & 6.75 \\
\hline MIN & & & & 4.12 & 1.26 & 5.97 & 6.58 \\
\hline MAX & & & & 25.18 & 96.73 & 155.17 & 6.97 \\
\hline STD.V & & & & 11.10 & 44.48 & 70.22 & 0.16 \\
\hline
\end{tabular}

Table 9 Heavy metals concentrations in water samples ふample Latitude Longitude Heavy metal concentration (ppm) pH

\begin{tabular}{|c|c|c|c|c|c|c|c|}
\hline & & & & & & & \\
\hline & $\mathrm{Cd}$ & $\mathrm{Cr}$ & $\mathrm{Cu}$ & $\mathrm{Pb}$ & \\
\hline NS C & $5.684598 \mathrm{~N}$ & $0.026144 \mathrm{~W}$ & 0.03 & 11.95 & 5.84 & 5.89 & 7.55 \\
\hline NS 1 & $5.683145 \mathrm{~N}$ & $0.029027 \mathrm{~W}$ & 0.49 & 12.28 & 217.98 & 44.77 & 7.49 \\
\hline NS 2 & $5.683328 \mathrm{~N}$ & $0.028788 \mathrm{~W}$ & n.d & n.d & n.d & n.d & 7.61 \\
\hline MEAN & & & 0.26 & 12.12 & 111.91 & 25.33 & 7.55 \\
\hline MIN & & & 0.03 & 11.95 & 5.84 & 5.89 & 7.49 \\
\hline MAX & & & 0.49 & 12.28 & 217.98 & 44.77 & 7.61 \\
\hline รTD.V & & & 0.33 & 0.23 & 150.00 & 27.49 & 0.06 \\
\hline
\end{tabular}

\section{Figures}



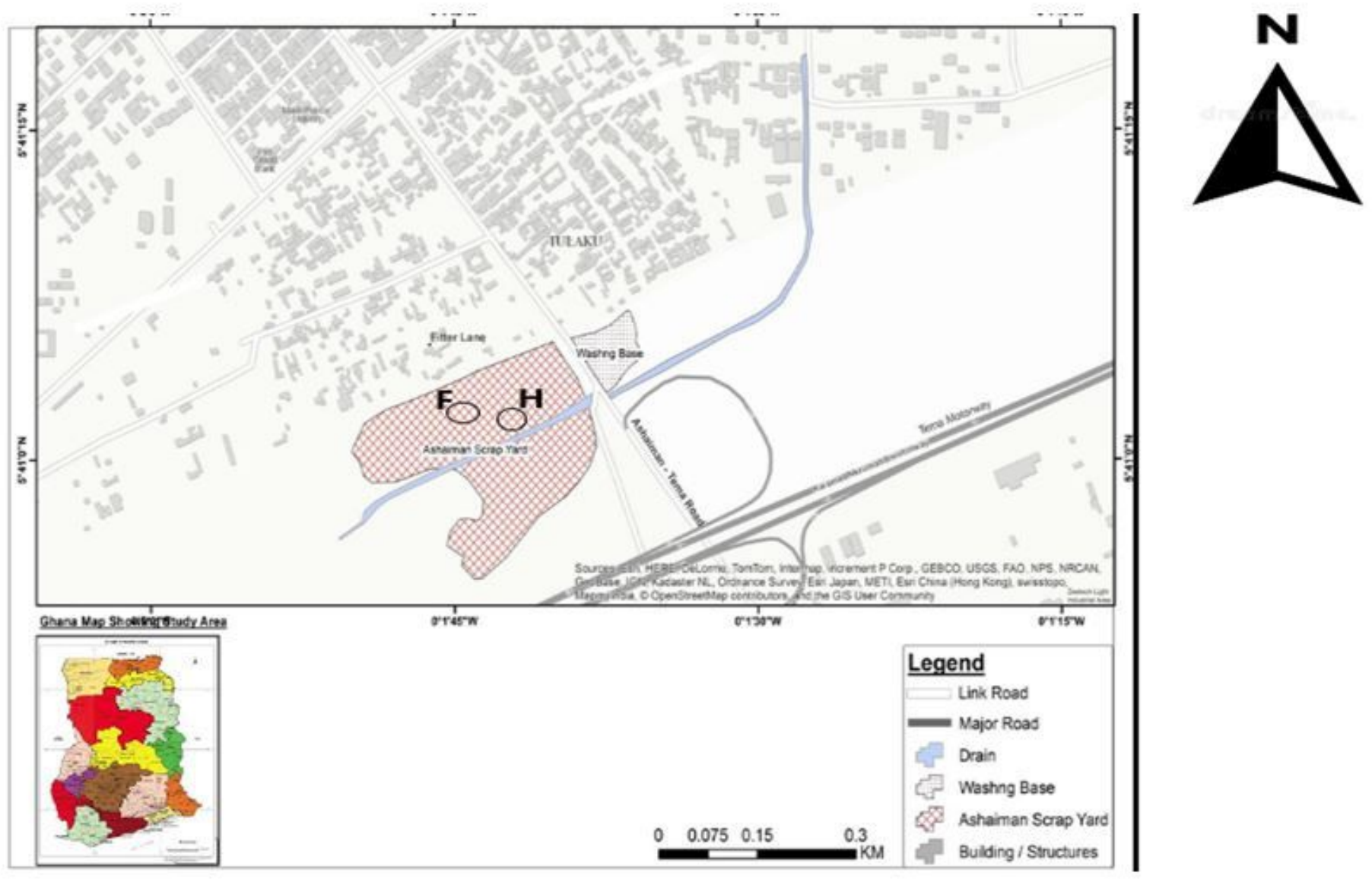

Figure 1

Map showing scrapyard at Ashaiman (Adapted from Okine [13]) 
Sub Soil Metal (Cd) Concentration Map

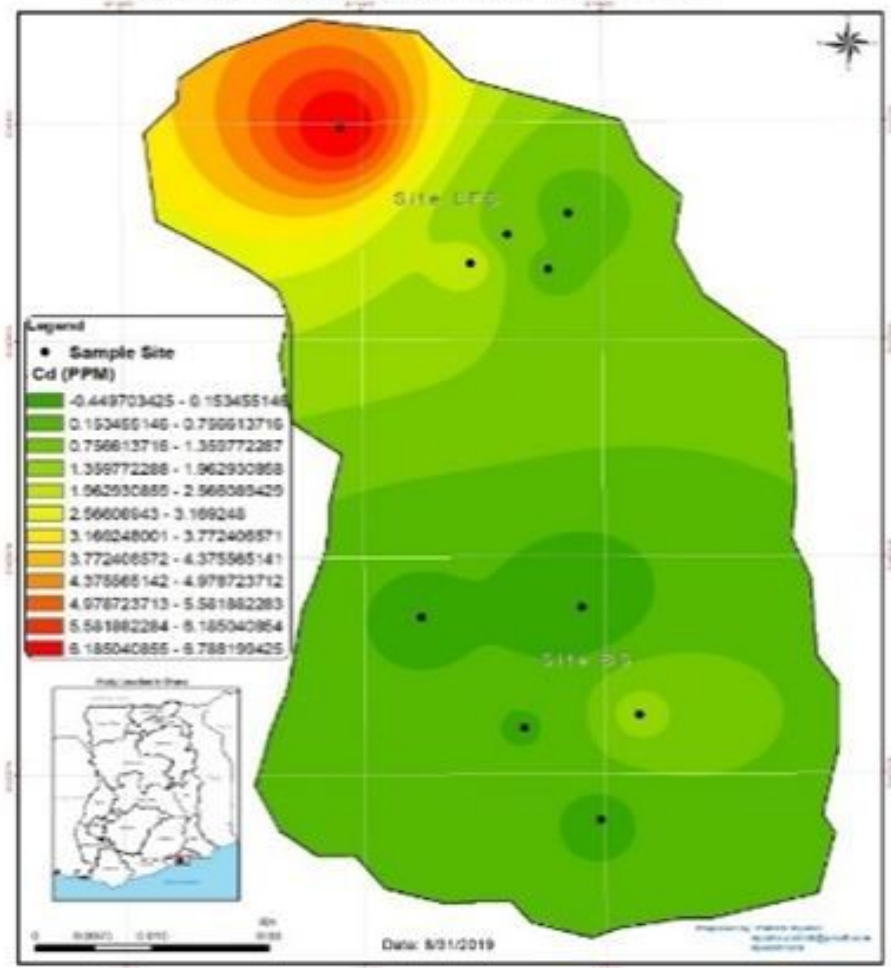

Top Soil Metal (Cd) Concentration Map

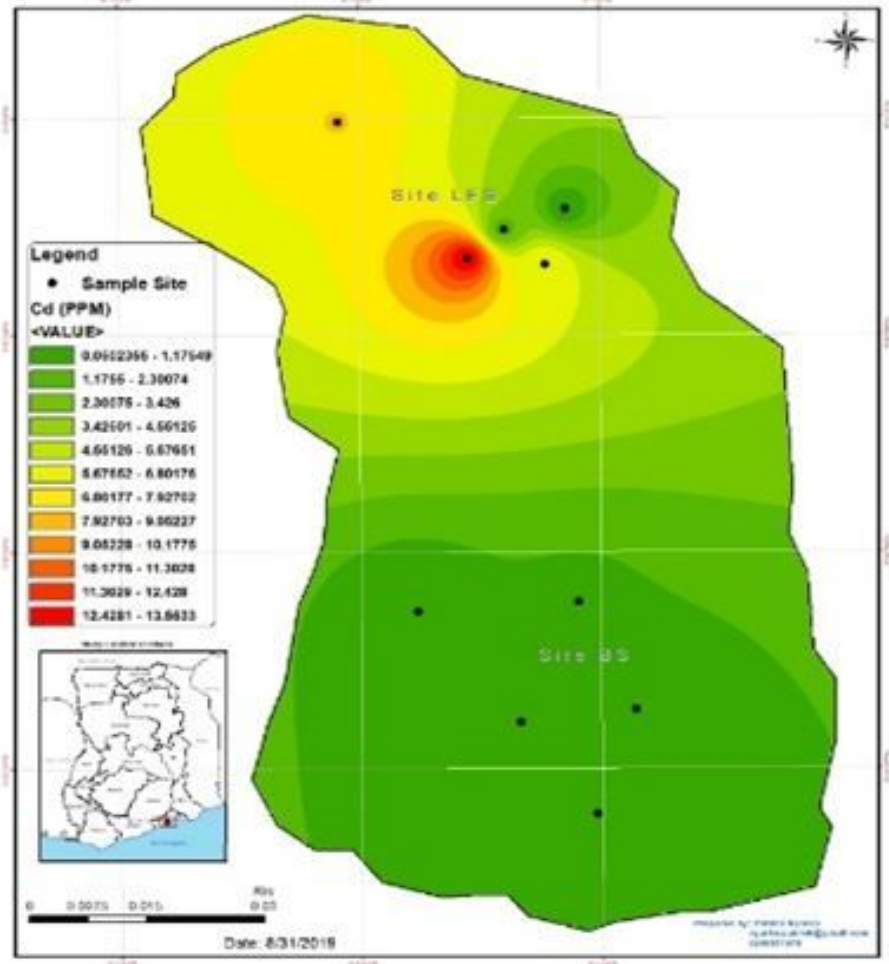

Figure 2

Spatial distributions of $\mathrm{Cd}$ in subsoil (L) and topsoil (R) of sites $\mathrm{F}$ and $\mathrm{H}$

Sub Soil Metal $(\mathrm{Cr})$ Concentration Map

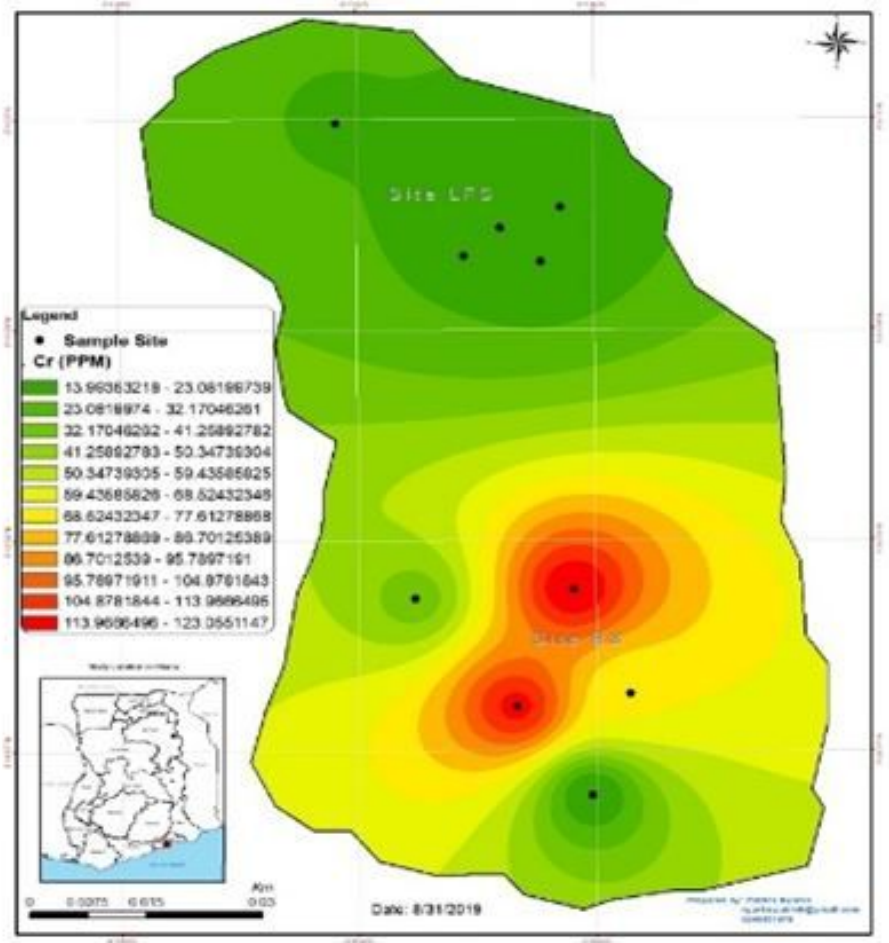

Top Soil Metal ( $\mathrm{Cr})$ Concentration Map

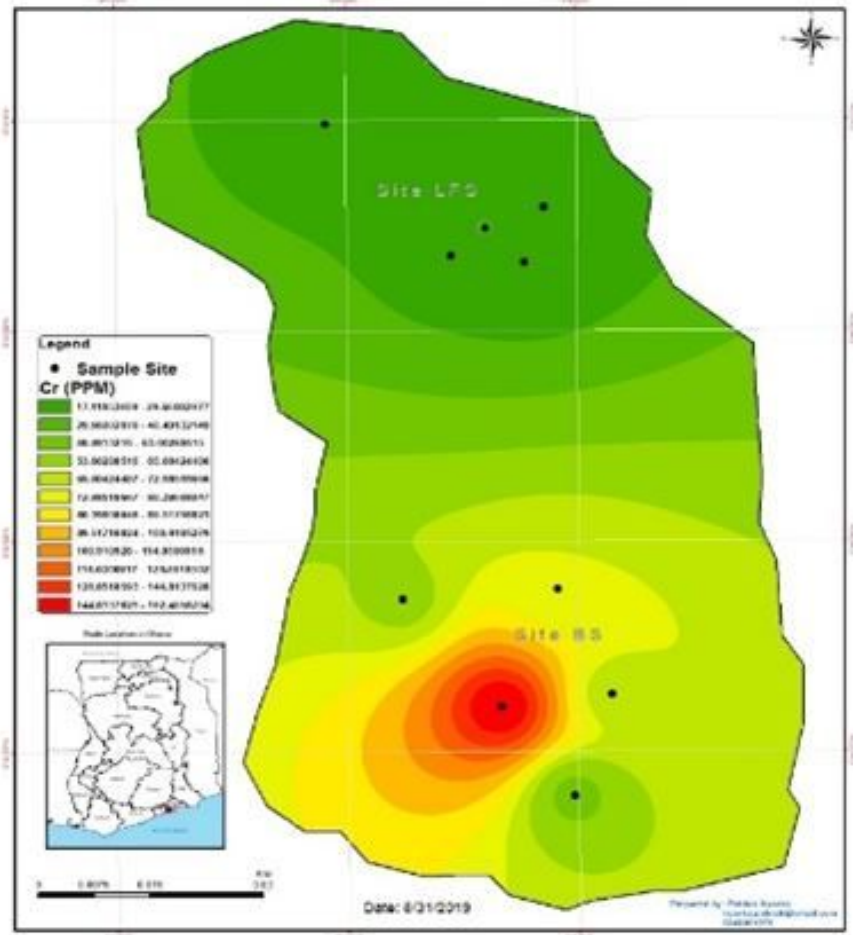

Figure 3 
Spatial distributions of $\mathrm{Cr}$ in subsoil $(\mathrm{L})$ and topsoil $(\mathrm{R})$ of sites $\mathrm{F}$ and $\mathrm{H}$

Sub Soil Metal (Cu) Concentration Map

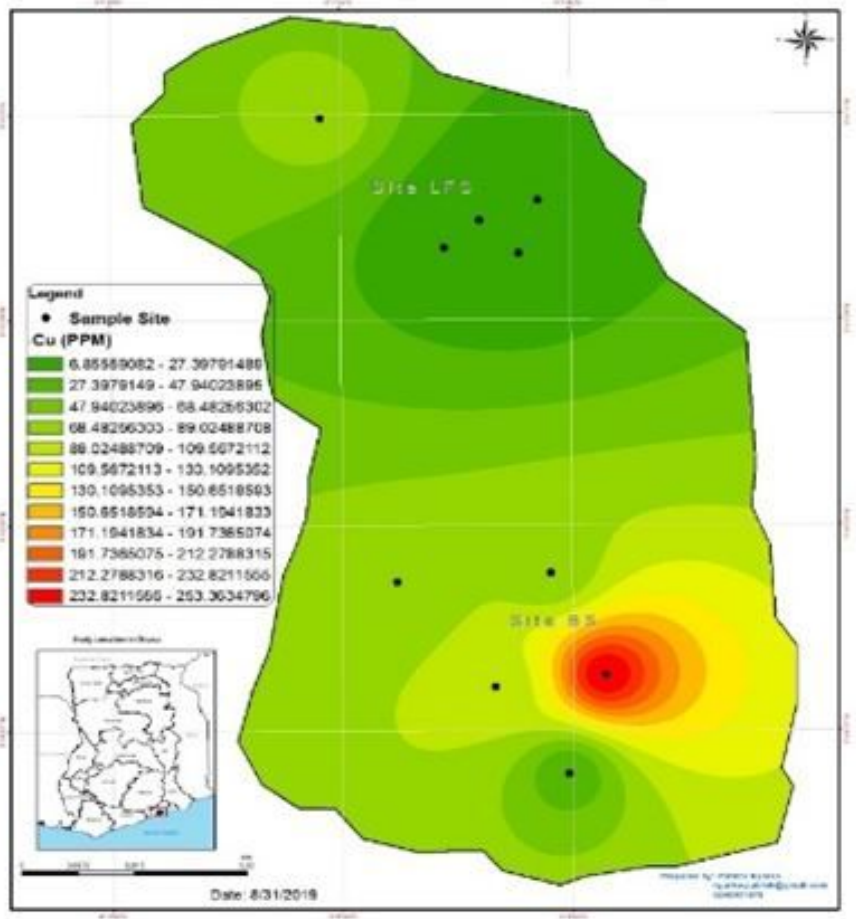

Top Soil Metal (Cu) Concentration Map

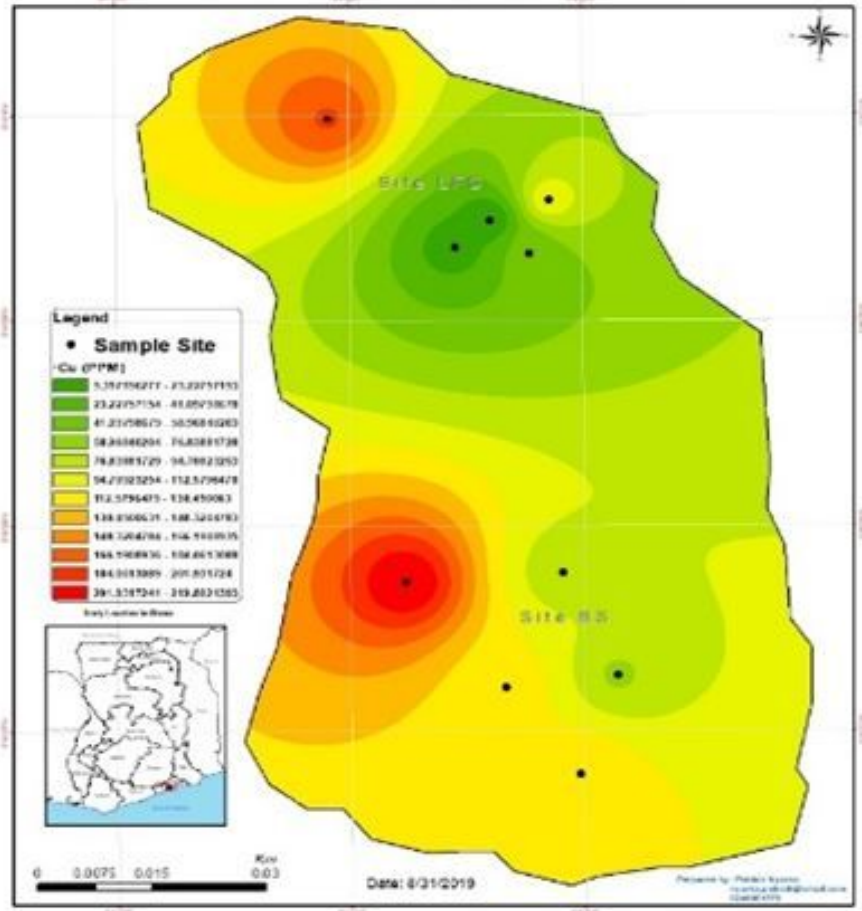

\section{Figure 4}

Spatial distributions of $\mathrm{Cu}$ in subsoil ( $\mathrm{L}$ ) and topsoil (R) of sites $\mathrm{F}$ and $\mathrm{H}$
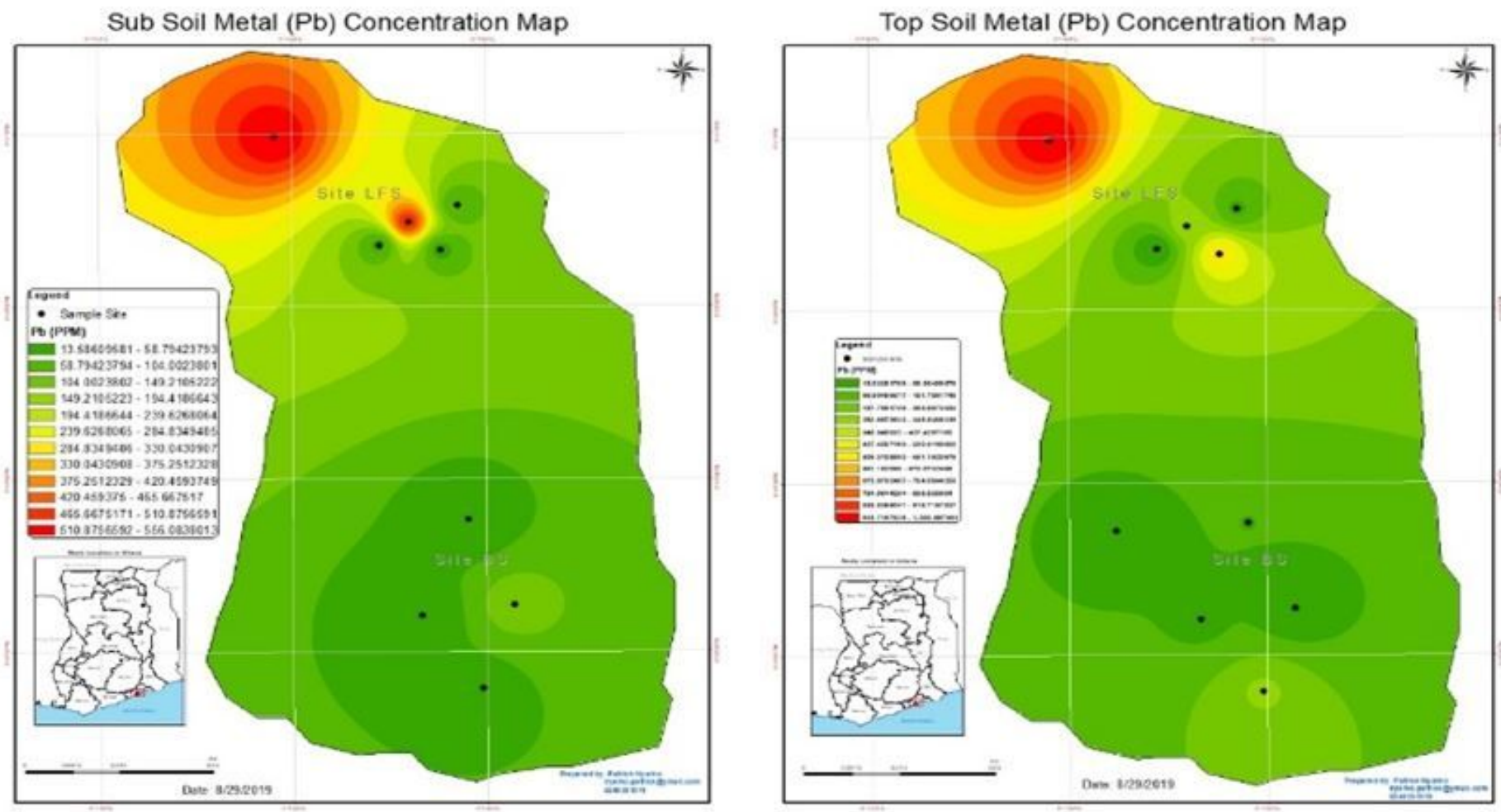

Figure 5 
Spatial distributions of $\mathrm{Pb}$ in subsoil $(\mathrm{L})$ and topsoil $(\mathrm{R})$ of sites $\mathrm{F}$ and $\mathrm{H}$ 